UNIVERSIDADE DE SÃO PAULO

INSTITUTO DE PSICOLOGIA

Ísis Gomes Vasconcelos

Comportamento moral e responder relacional

São Paulo 


\section{ÍSIS GOMES VASCONCELOS}

\section{Comportamento moral e responder relacional}

\section{Versão original}

Tese apresentada ao Instituto de Psicologia da Universidade de São Paulo para obtenção do título de Doutora em Psicologia.

Área de Concentração: Psicologia Experimental

Orientador: Prof. Dr. Marcelo Frota Lobato Benvenuti

São Paulo 
Trabalho parcialmente financiado pelo CNPq - Conselho Nacional de Desenvolvimento Científico e Tecnológico, processo \#142217-2016-6

E realizado no context o do Instituto Nacional de Ciência e Tecnologia sobre Comportamento, Cognição e Ensino coordenado pela Profa. Deisy das Graças de Souza, processos FAPESP (\#2008/57705-8) e CNPq (\#573972-2008-7). 
Nome: Vasconcelos, Ísis Gomes

Título: Comportamento moral e responder relacional

Tese apresentada ao Instituto de Psicologia da Universidade de São Paulo para obtenção do título de Doutora em Psicologia

Aprovada em:

\section{Banca Examinadora}

Prof. Dr.

Instituição:

Julgamento:

Prof. Dra.

Instituição:

Julgamento:

Prof. Dra.

Instituição:

Julgamento:

Prof. Dr.

Instituição:

Julgamento:

Prof. Dr.

Instituição:

Julgamento:

Prof. Dr.

Instituição:

Julgamento: 


\section{Agradecimentos}

O ofício de pesquisador é árduo. É um processo ao mesmo tempo criativo e rigoroso. Instigante e desgastante. Demanda de nós a energia para criar o que ainda não existe (a famosa contribuição original), apoiados nos ombros uns dos outros. Ao fim deste trabalho, um percurso de anos, tenho a felicidade de contar com várias pessoas maravilhosas e com oportunidades que me foram dadas e que fizeram este momento possível.

Agradeço primeiramente ao Cnpq, pelo incentivo por meio da bolsa de estudos. Esta bolsa foi condição necessária para a realização deste doutorado, do primeiro ao último dia. Sem ela, este trabalho que aqui apresento e o treinamento que recebi não seriam possíveis. A oportunidade de uma bolsa de estudos pode mudar vidas, abrir caminhos. Foi assim comigo, e por isso sou muito grata. Agradeço também ao departamento de psicologia experimental por oferecer as condições para a realização deste doutorado.

Entre as pessoas que fizeram parte dessa caminhada, preciso tecer agradecimentos especiais ao meu orientador neste trabalho, Marcelo e ao meu orientador do mestrado, João Claudio Todorov. Com vocês eu aprendi (não que este trajeto esteja concluído) o ofício do pesquisador e, em especial, o da condução de experimentos. Desde o trato com o texto, com a escrita, o planejamento de procedimentos, tudo o que faz parte do treino de um pesquisador. Aprendi também o respeito no debate de ideias. Aprendi que divergências teóricas e epistemológicas são terreno fértil para uma produção de conhecimento rigorosa e útil. Como Todorov sempre dizia:" Você pensa desse jeito, então escreva sobre isso!". Marcelo, você é um exemplo de professor e pesquisador. Obrigada por sua atenção e suas críticas, sempre pertinentes. 
Agradeço também os professores Paula, Renato, Alexandre, Júlio, Thaís e todos os membros da banca por ter em aceitado o convite para apreciar este trabalho e me ajudar a crescer com ele.

O ambiente do doutorado permitiu que eu conhece muitas pessoas, pesquisadores competentes que debateram este trabalho comigo e que também se tornaram amigos para a vida. Carla, César, Jéssica e Eduardo, vocês tornaram as aulas e a pesquisa muito mais instigantes e tornaram a vida em São Paulo muito mais feliz.

Família querida, minha mãe Lucineide, meu pai Edmilson, meus irmãos Filipe e Laís, este trabalho também é fruto do apoio incondicional que vocês sempre me deram para sair de Aracaju e procurar a formação em Análise do Comportamento que era meu objeto de desejo. É fruto do amor, carinho e companheirismo de vocês. Sem vocês eu não conseguiria.

Dante, meu querido, as palavras não chegam para expressar meu amor, admiração e gratidão a você. Você fez parte de todo esse percurso como um companheiro cuidadoso, e um leitor interessado e crítico. Pude me beneficiar grandemente de sua formação de pesquisador em filosofia, de seus questionamentos e suas revisões criteriosas sobre meus textos. Obrigada por aliviar a carga deste trabalho e do dia-a-dia. Me sinto muito feliz por compartilhar a vida com você. 
"We do not choose survival as a value, it chooses us." B. F. Skinner 


\section{RESUMO}

Vasconcelos, Í. G. (2020). Comportamento moral e responder relacional (Tese de Doutorado). Instituto de Psicologia, Universidade de São Paulo, São Paulo.

Este trabalho apresenta uma abordagem experimental da moralidade orientada pela noção de multideterminação do comportamento e o princípio de seleção por consequências. É composto por um trabalho de revisão da produção experimental sobre a moralidade e uma proposta empírica de investigação dos valores morais endereçada em dois experimentos. $\mathrm{O}$ estudo experimental da moralidade é dedicado à investigação de variáveis distais, presentes na história da espécie, e variáveis proximais, identificáveis na história de vida do organismo. A partir disso, oferece descrições como os seres humanos classificam as condutas em certas ou erradas e utilizam essas classificações para pautar o próprio comportamento e produzir consequências para o comportamento de seus pares a fim de coibir o egoísmo e favorecer interesses coletivos. No nível proximal de análise, o estudo dos valores que subordinam as condutas é majoritariamente apoiado numa análise dos usos dos termos valorativos, tendo o comportamento verbal como dado principal. Sustentamos neste trabalho que a diversidade de convenções culturais, dos temas que compõem normas de obrigações, permissões e proibições num grupo, pode ser investigada por meio de procedimentos de responder relacional, tomando como base a literatura sobre comportamento simbólico. A parte empírica deste trabalho propõe o uso do procedimento de avaliação de relações implícitas (implicit relations assessment procedure - IRAP) como uma alternativa ao uso de procedimentos de autorrelato para a identificação de valores de justiça e pureza. O dado básico do IRAP é a latência média da resposta a conjuntos de estímulos verbais consistentes ou não entre si. No primeiro estudo, 20 participantes primeiro responderam ao questionário de bases morais (Moral Foundations Questionnaire - MFQ) e, em seguida, a um IRAP apresentando os mesmos conteúdos sobre justiça e pureza. Os resultados diferiram a depender do procedimento. No questionário os participantes apresentaram alta frequência de concordância com valores de pureza e alta frequência de discordância com valores de pureza. No IRAP, a frequência de concordância foram aproximada entre os dois valores. O Estudo 2 introduziu uma comparação entre dois grupos pré-experimentalmente diferentes a fim de verificar se os procedimentos seriam capazes de corretamente diferenciar os participantes de um e outro grupo com base em suas respostas a valores de pureza e justiça. A variável pré-experimental verificada foi a presença ou ausência de vivência religiosa do participante. A literatura do MFQ demonstra que participantes religiosos tendem a demonstrar concordância com ambos os valores enquanto participantes não religiosos tendem a demonstrar concordância com valores de justiça e discordância de valores de pureza. Ambos os procedimentos apontaram diferenças estatisticamente significativas no padrão de resposta em função do grupo, mas o desempenho dos participantes foi, assim como no Estudo 1, diferente em função do procedimento. Os resultados do MFQ no Estudo 2 reproduziram o padrão observado na literatura enquanto os resultados do IRAP indicaram ausência de concordância com valores de pureza entre os participantes religiosos. Concluímos apresentando questões futuras para a pesquisa experimental sobre valores morais.

Palavras-chave: Moralidade. Responder relacional. Autorrelato. Valores 


\begin{abstract}
Vasconcelos, Í. G. (2020). Moral behavior and relational responding (Tese de Doutorado). Instituto de Psicologia, Universidade de São Paulo, São Paulo.
\end{abstract}

The current work presents an experimental approach of morality guided by the notion of multi-determination of behavior and the principle of selection by consequences. It is composed by a theoretical ensemble of the experimental production on morality and an empirical approach on moral values addressed in two experiments. The experimental study of morality is dedicated to the investigation of distal variables, presented in the history of the species and proximal variables, identifiable in the organism's life history. Parting from this, it offers descriptions of how human beings classify conducts in right or wrong and apply such classifications as a guide to its own behavior and to produce consequences to the behavior of its pairs in order to curb selfishness and favors collective interests. In the proximal level of analysis, the study of the values underlying conducts is mostly addressed in analysis of the uses of evaluative terms having verbal behavior as main data. We sustain that the diversity of cultural conventions, of the themes that composes norms of obligation, permission and prohibition in a group can be adequately described by procedures on relational responding, taking as a foundation the literature on symbolic behavior. The empirical part of this work proposes the use of the implicit relations assessment procedure - IRAP as an alternative to the use self-report procedures as means to the identification of values of fairness and purity. IRAP's basic data is the mean latency of response to sets of verbal stimuli consistent or not among them. In the first study, 20 participants first responded to the moral foundations questionnaire - MFQ and then to an IRAP presenting the same content on fairness and purity. Results differed depending on the procedure. In questionnaire participants indicated high frequency of agreement with values of fairness and high frequency of disagreement with values of purity. In IRAP, agreement biases were similar to both values. Study two introduced a comparison between two pre-experimentally distinct groups aiming to verify if both procedures would correctly differentiate participants from one or another group. The preexperimental variable verified was the presence or absence of religious experience in participant's history. MFQ literature shows that religious participants tend to demonstrate agreement with both values whereas non religious participants tend to demonstrate agreement with values of fairness and disagreement with values of purity. Both procedures showed statistically significant differences in response patterns depending on the group, but participant's performance, as in study 1, differed between procedures. Results from MFQ reproduced the pattern observed in literature while results from IRAP indicated absence of agreement on purity values among religious participants. We conclude by presenting further research issues on the experimental research on moral values.

Keywords: Morality. Relational Responding. Self-report. Values. 


\section{LISTA DE TABELAS}

Tabela 1 - Trial types presented in practice phase.

Tabela 2 - Trial types presented in test phase.

Tabela 3 - Method to convert mean latencies from each participant in D - IRAP scores. 


\section{Lista de Figuras}

Figura1 - Group means of agreement for each of the five foundations in MFQ .72

Figura 2 - Individual mean latencies for statements on fairness .74

Figura 3 - Individual mean latencies for statements on purity .76

Figura 4 - D - IRAP scores for each one of the trial types .77

Figura 5 - Frequency of agreement within the six statements in the questionnaire (explicit) and IRAP (implicit).... . .80

Figura 6 - Média de concordância para cada uma das cinco bases morais por grupo .98

Figura 7 - Latências médias individuais nos blocos consistentes e inconsistentes para cada uma das três afirmações sobre justiça. 101

Figura 8 - Latências médias individuais nos blocos consistentes e inconsistentes para cada uma das três afirmações sobre pureza. 103 


\section{SUMÁRIO}

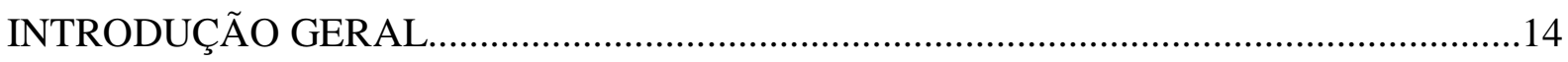

CAPÍTULO 1: Moral behavior: A theoretical and empirical bond for culturo-behavior

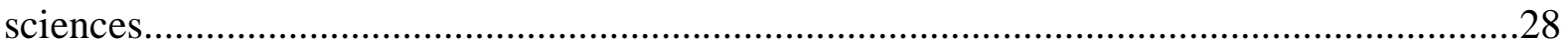

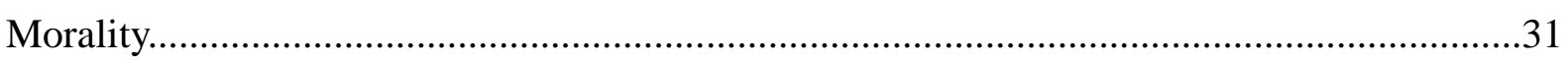

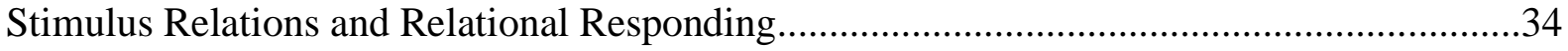

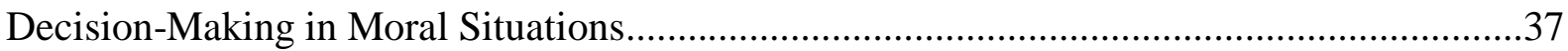

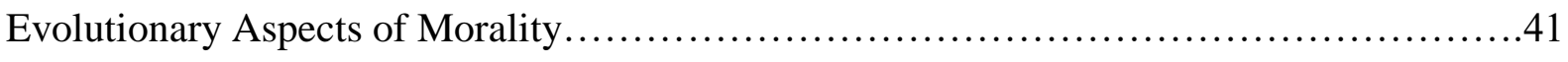

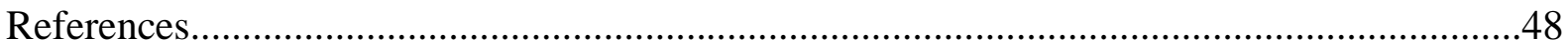

CAPÍTULO 2: An empirical investigation on moral values: explicit and implicit values of

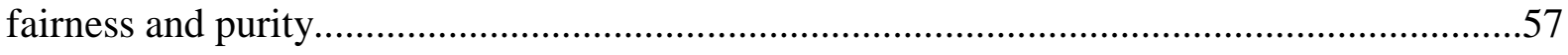

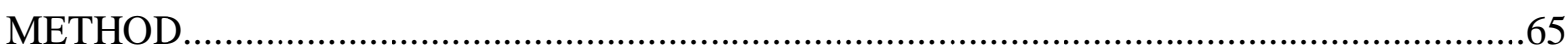

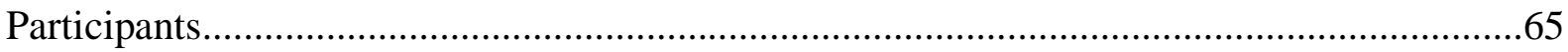

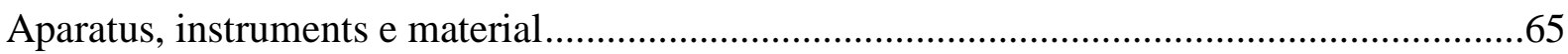

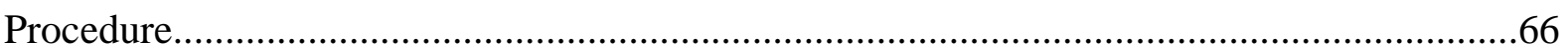

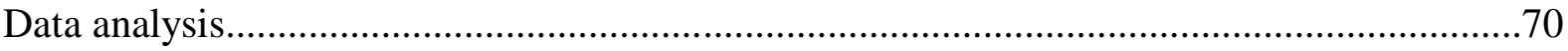

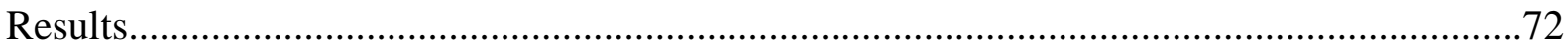

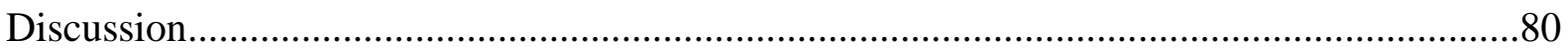

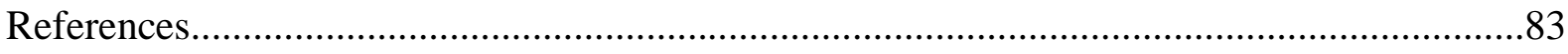

CAPÍTULO 3: Religiosidade como preditora de valores morais de justiça e pureza em

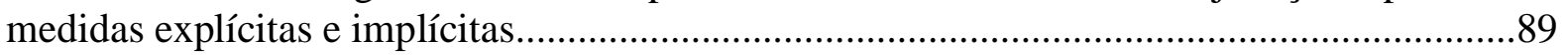

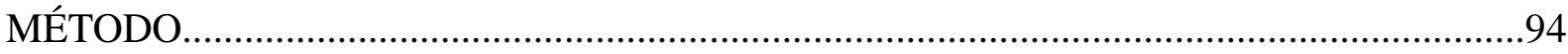

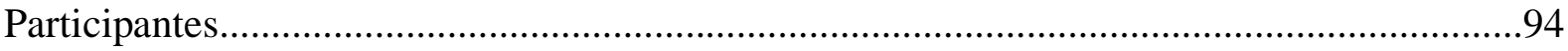

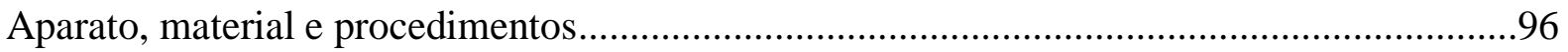

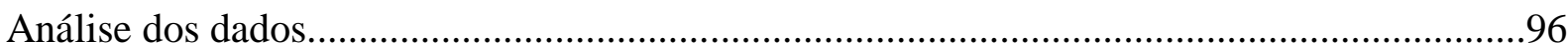

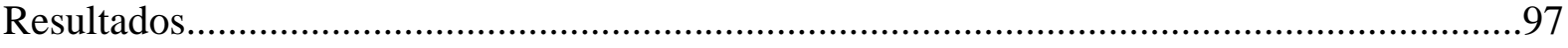

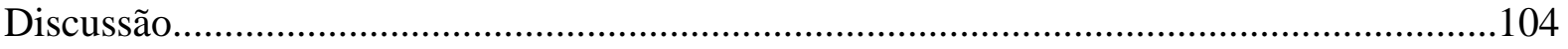

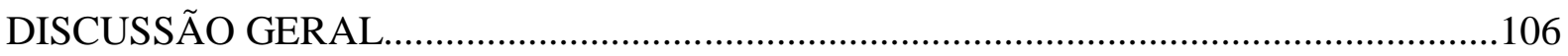

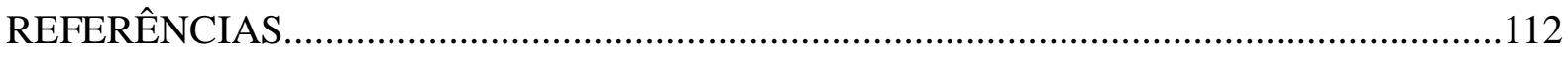

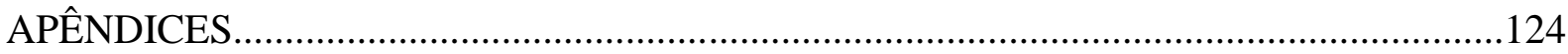

